\title{
Mobile-Assisted Learning as a Condition for Effective Development of Engineering Students' Foreign Language Competence
}

\author{
Vassiliy Andreevich Krivoruchko ${ }^{1}$, Aigul Bekturovna Raissova ${ }^{1}$, Inna Mikhailovna Makarikhina ${ }^{1}$, Gulnar \\ Dzumabayevna Yergazinova $^{1} \&$ Bayan Ruslanovna Kazhmuratova $^{1}$ \\ ${ }^{1}$ S. Toraighyrov Pavlodar State University, Kazakhstan \\ Correspondence: Vassiliy Andreevich Krivoruchko, S. Toraighyrov Pavlodar State University, Pavlodar 140008, \\ Kazakhstan.
}

Received: January 31, 2015 Accepted: March 6, 2015 Online Published: June 29, 2015

doi:10.5539/ies.v8n7p158 URL: http://dx.doi.org/10.5539/ies.v8n7p158

\begin{abstract}
In this article we focus on the conditions for effective development of foreign language competence that is technologically oriented methods of teaching a foreign language. The use of computers provides ample opportunities for implementation of activity and student-centered approaches, reorganization of the usual lesson structure, as well as providing the students with more autonomy. Currently, due to the extensive use of wireless devices, there is a new form of e-learning i.e. mobile learning. The experimental results showed that the use of mobile electronic multimedia courses increase the effectiveness of foreign language teaching, as in the absence of a real language environment, creates opportunity for immersion in an authentic foreign language environment, improve language competence in all kinds of speech activity, all of which leads to the development of students' foreign language competence. These tools allow achieving results with less expenditure of time and effort, which is also an indicator for the efficiency of mobile learning means application in the development of foreign language competence.
\end{abstract}

Keywords: e-learning, mobile learning, engineering students' foreign language competence, English for Specific Purposes

\section{Introduction}

In the educational system of Kazakhstan the process of informatization is going on at all levels. In order to be among the advanced countries, the management of the educational process must be fully computerized for ensuring the normal operation of large and small groups. Thus, the basis for an educational system that meets world standards, is the need for computerization of the educational process and its objects (Pfeifer \& Zhumatayeva, 2006).

"It is recognized now that the education system of any country, absorbed the best achievements of foreign educational systems, retaining and developing the national roots of the system, will make a huge contribution to the social, economic and political future of the country", said the academician Kussainov (2008).

Mobile learning can be seen as the next generation of e-learning. This type of learning is characterized as a spontaneous, informal, personalized and ubiquitous. In this article we consider the effective learning using mobile technology.

\section{Theoretical Background of Mobile-Assisted Language Learning}

With regard to language learning, the modern information technologies really offer innovative ways of teaching and learning, such as easy access to study materials, individual pace, as well as the time and place for study, almost immediate feedback, the ability to self-knowledge.

Based on the problems and challenges of research, we need:

- To consider the components, didactic principles and criteria of the effectiveness of information technology as a resource for student-centered learning a foreign language for specific purposes;

- To develop and experimentally implement pedagogical support for the development of engineering students' foreign language competence.

Long, before e-learning, Plato (428-348 B.C.) said that someday in the distant future, the descendants would 
develop a new equivalent of classrooms, they would spend many hours sitting in front of the boxes glowing inside. Further, he added that he hoped they would have enough wisdom to understand the difference between light and true knowledge (Mullamaa, 2010).

In our study, the problem of using information technology demanded the study and analysis of the works by Obraztsov (2001), Burimskaya (2008), Minkova (2005), Zaitseva (2004) and other scientists.

Obraztsov (2001) reveals in his study the essence of the concept of information technology support, based on the didactic unity of "substantive and procedural sides of learning." The scientist reveals the essence of the concepts of "information component", "technological component." "...The information component is a didactic complex system, in which the applied learning software products are integrated for supporting the training process as well as the totality of other didactic tools..."

Technological component (according to Obraztsov) is a learning process organization "on the base of the modern learning technology (LT) use." LT is the "pivot with the information environment around" (Obraztsov, 2001).

Minkova (2005) investigates integrated approach on the aspects of traditional education, pedagogical innovations, communication technologies in forming of students-linguists' foreign language communicative competence.

The didactic principles, binding objectives and content of Bachelor preparation with learning process laws serves as the main provisions which define the educational process planning, organization and teaching disciplines methodology. Principles of learning according to Zaitseva (2004) are a "guiding ideology, the regulatory requirements for the organization and educational process implementation."

In general, science researchers identified the following principles for the mobile-assisted learning use, oriented on bachelors' preparation in a university: science, activity, awareness, visibility, accessibility, systematic sequence and learning professional orientation.

Burimskaya (2008) gives a detailed description of those principles in his study. Specific principles of language computer learning were taken into account in e-learning and multimedia course preparation: modularization content material polytouch, interactivity, choice of tempo, material difficulty, voice direction, situational, functional and personal alignment.

Based on the analysis of the scholars' works we can conclude that the means of mobile-assisted learning is the set of wireless means and methods of their use in teaching English and, at the same time, these devices are considered as specific means, "tools" in a teacher hands, following him to organize the teaching process at the technological level

\subsection{Advantages and Disadvantages of Mobile-Assisted Language Learning}

Mobile technologies offer a variety of language learning tools: laptops, netbooks, tablets, mobile phones, etc. In many cases, they are readily available, cheaper than standard equipment, such as a computer. Portability of mobile agents is another advantage.

Despite its advantages, there is also a number of disadvantages: small screen, limited audiovisual contact, small keyboard, the limited length of messages, etc.

At the same time, the e-learning environment has a certain number of advantages and disadvantages:

Advantages:

- $\quad$ Easy access to learning materials;

- Access to resources;

- Individual: pace, time, and place of study;

- Almost immediate feedback;

- Increasing students' motivation and encouraging them;

- The modern way of learning;

- The teacher may be absent;

- The possibility of self-practice and knowledge testing;

- More opportunities for consultation, communication;

- Work in a team;

- Providing with a large amount of tasks and their immediate assessment; 
- Simple operation and stability;

- Attractiveness and dynamism;

- The possibility of distance learning.

Disadvantages:

- Lack of personal contact, which is especially necessary for language learning;

- Problems with the equipment, the lack of computers;

- The high price of access "online" for students;

- Sometimes, the lack of feedback.

The use of electronic means is a process aimed at improving the quality of learning process. Together with some shortcomings there is a certain number of advantages.

Mobile learning represents the next generation of information technology.

Among all the modern communication devices, mobile phones, despite the technical limitations are the most popular means of communication in comparison with e-mail, forums or chat.

E-learning allows students to study material not in the classroom, but at home online or offline. Mobile learning provides students with possibilities to learn anywhere and at any time.

Two main characteristics of mobile devices: portability and ubiquitous connectivity to learning materials. The following properties of mobile devices as mobility, social interactivity, data exchange and the possibility of cooperation with other students via mobile devices, context sensitivity, connectivity to other devices, individuality can be selected.

According to Japanese researcher T. Yamaguchi, a computer is running better than a mobile phone in the processing of visual, audio and textual information, and the mobile phone is superior to computer in portability. In addition, some students do not have their own computers (Yamaguchi, 2005).

\subsection{Pedagogical Support for Development of Engineering Students' Foreign Language Competence}

At the present stage in Kazakhstan there is a plenty of foreign training courses (and a few national ones), print and multimedia, for conversational and business communication skills development.

During writing teaching materials (TM) for professional English we have such basic aspects as:

- Authentic English sources on technical disciplines;

- Internet sites on the disciplines;

- Teaching English aids on technical disciplines;

- Images of business communication in English;

- Forums and conferences.

Based on our last 4 years' experience, according to the timetable ( 3 hours for classroom and 2 hours for self-study with the teacher in a foreign language), it is difficult to organize oral speech practice due to the time shortage. However, English speech development is achieved in a number of departments, only through the use of additional oral conversation practice classes. In this respect, the means of mobile technologies represent a great opportunity to practice outside of class. Students have the opportunity to engage in the subject at any time and in any place. Students downloaded the e-learning courses, dictionaries for mobile phones and laptops, netbooks, tablets. Self-study materials are prepared by the students themselves and sent by e-mail to the teacher.

Bashmakova (2003) writes in her study, the widespread use of role-playing elements and business games, along with the use of information technology optimizes the educational process. Organizing educational proses, you should take into account students' psychological characteristics, study their age features' psychological parameters.

\subsubsection{Substantial Component of Pedagogical Support}

Pedagogical and didactic requirements of electronic textbooks (ET) were developed in order to create electronic and multimedia courses in the Center of Informatization of S.Toraighyrov Pavlodar State University:

1) Logical and consistent material presentation, proper use of professional terms, scientific and accessible style, required level of a text complexity, availability, expressive language, language precision, etc.; using exact titles, focus on collective and individual learning abilities; 
2) Reflection of integrity and system threads partition theory;

3) Skills and habits formation (examples of assignments, etc., formation of generalized and practical abilities, skills independently formulate and solve problems);

4) Visibility of teaching and research patterns, theories, concepts.

5) Learning durability with the using of electronic resources (ER). The use of ER gives the opportunity to organize multiple repetitions as varied activities and increases variability of controlled individual learning tasks.

6) Methodological requirements are ER techniques implementation, technology training, appropriateness of ER multimedia elements use, components.

7) The program should provide concurrent users locally and via web interface.

Kalmanova D.M. (Kalmanova, 2009) studies to enhance students' cognitive interests, using electronic textbooks and offers the following components: motivational target component, substantial component, operational component, assessment and effective component.

In our study, we took motivational, informative and evaluative criteria for the application of mobile-assisted learning in foreign languages studying as the basis ones.

In the context of our study the substantial component of pedagogical support for the development of engineering students' foreign language competence is: TM for elective course "Technical Translation", English e-learning courses for Kazakh and Russian language studying groups, teaching aids: "English for Specific Purposes", "English-Russian-Kazakh dictionary for Physics, Mathematics and Computer Science", "English-Russian-Kazakh lingvotrainer for Technical specialties".

Foreign language competence needs a reliable language (phonetic, lexical, grammatical and terminological) basis.

English e-learning courses for engineering students of Kazakh and Russian groups were developed in order to form students' lexical and grammatical skills at the Foreign Languages Department of Pavlodar State University named after S. Toraighyrov.

"English for Specific Purposes" textbook for groups with Kazakh and Russian languages, trilingual dictionary and lingvotrainer, electronic book "English for Specific Purposes" were written to form and develop terminology base, speaking skills in the field of professional communication. Multimedia course "Four Basis Skills" was written in order to control foreign language competence development according to four speech activities.

\subsubsection{Main Areas of Foreign Language Acquisition}

The structure of foreign language competence includes knowledge and skills acquired by students in the English language learning in two main areas: "Common" English (General English-GE) leaning and English leaning on a specialty (English for Specific Purposes-ESP). Information technology can be actively used in the teaching as "Common" English (GE) as English for Specific Purposes (ESP).

Assimilation is the basic concept of learning theories, the main content of training activities (Vygotsky, 1960; Skinner, 1968; Galperin, 1966; Leontiev, 1971; Rubinstein, 1989).

Common stages of mastering a foreign language were identified on the basis of the above-mentioned scientists' theoretical works. Stages are presented in Table 1. 
Table 1. Stages of foreign language acquisition

\begin{tabular}{|c|c|}
\hline Stage & Content \\
\hline $\begin{array}{l}\text { Conceptualization } \\
\text { Knowledge acquisition }\end{array}$ & $\begin{array}{l}\text { Process of removing observation concepts, process of formulating general nature } \\
\text { statements (Dictionaries and Encyclopedias, 2013) }\end{array}$ \\
\hline $\begin{array}{l}\text { Interiorization } \\
\text { Development of skills }\end{array}$ & $\begin{array}{l}\text { Formation of psyche internal structures by accumulation of positive social } \\
\text { activities individual results (Vygotsky, 1960) }\end{array}$ \\
\hline $\begin{array}{l}\text { Practice } \\
\text { Training-fixing knowledge } \\
\text { and skills }\end{array}$ & $\begin{array}{l}\text { Set of repetitive actions in a particular field of activity, aimed at acquiring } \\
\text { knowledge and skills, to atomize them (Leontiev, 1971) }\end{array}$ \\
\hline Application of knowledge and & skills in academic and professional situations \\
\hline
\end{tabular}

French scientist Piaget (2001) introduced the notion of conceptualization. The concept means: a person's ability to formulate ideas, mental concepts and abstractions. Leontiev (1971) explains in his study that any communication problems are solved within speech activity framework.

Thus, we conclude: foreign language competence is developed by mastering basic and advanced English. Stages of language acquisition: conceptualization, interiorization, training.

In this study, technical terminology acquiring is one of the key aspects of engineering students' foreign language competence. In our study, the term is considered as a concept.

\subsubsection{Technical English Terminology Mastering}

In connection with new technology application, there is necessary to master a wide range of technical terminology in addition neologisms in various fields of engineering. Teachers need to update quantity and variety of technical terminology, along with the use of this vocabulary in various technical disciplines. Technical English effective teaching to students depends on technical vocabulary science-based division. Effectiveness depends on the terms of mastering concepts in English.

The copyrighted electronic textbook (Figures 1-3) on "Foreign language (English)" discipline contains theoretical material and practical part, the extended help system is implemented using a multi-display technology training material that meets modern electronic textbooks requirements.

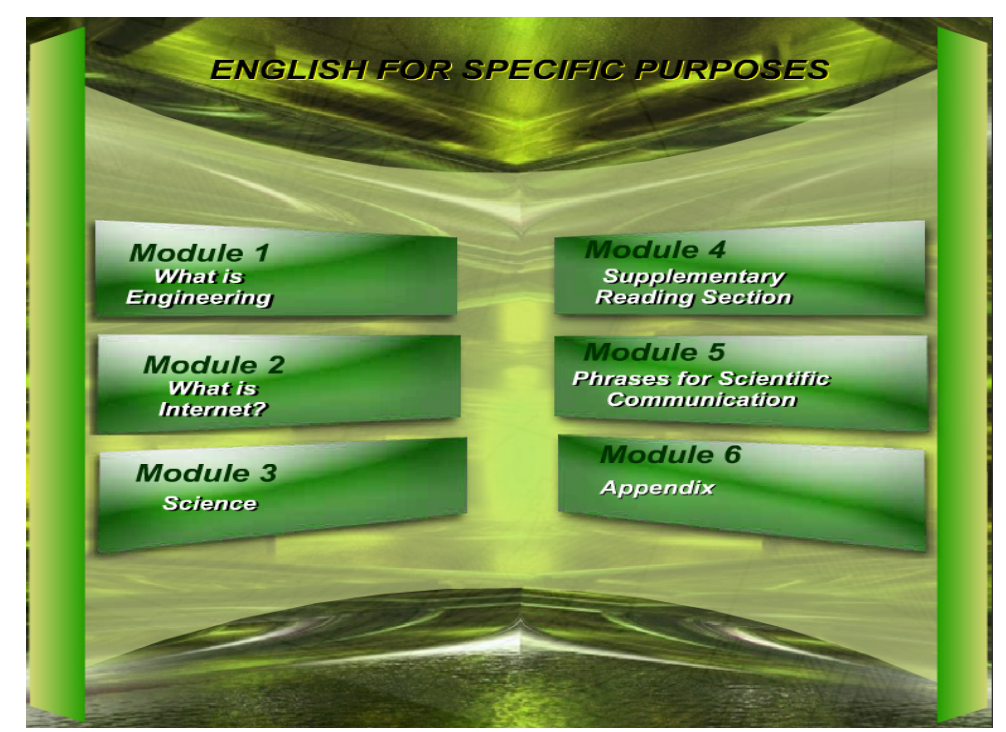

Figure 1. Menu 


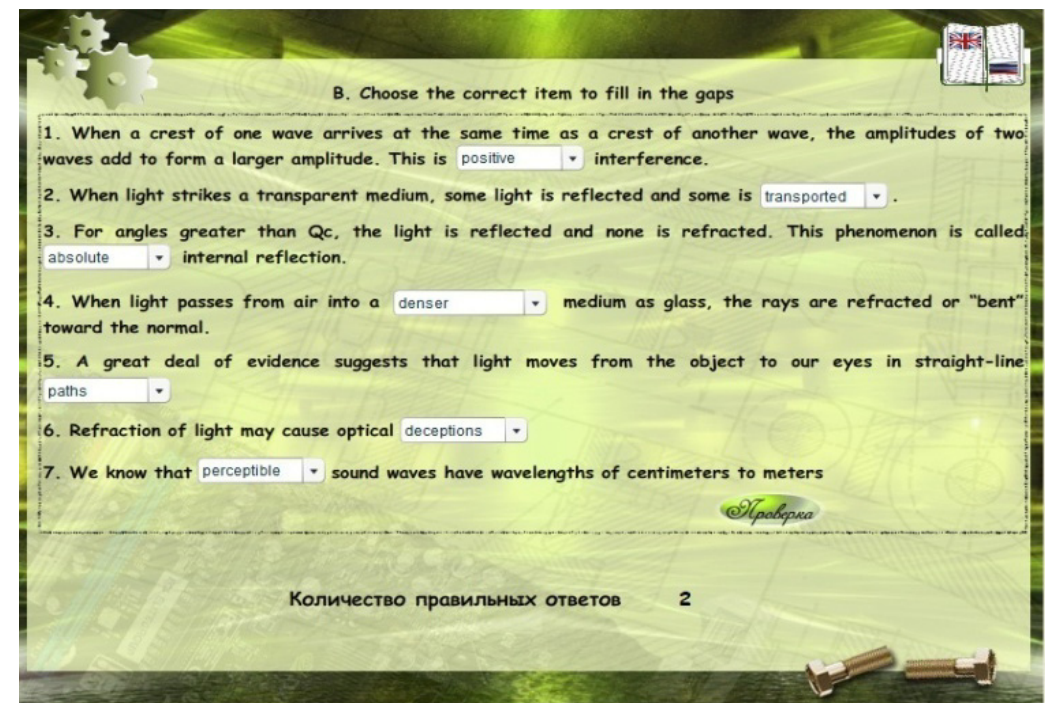

Figure 2. Frame for stepping

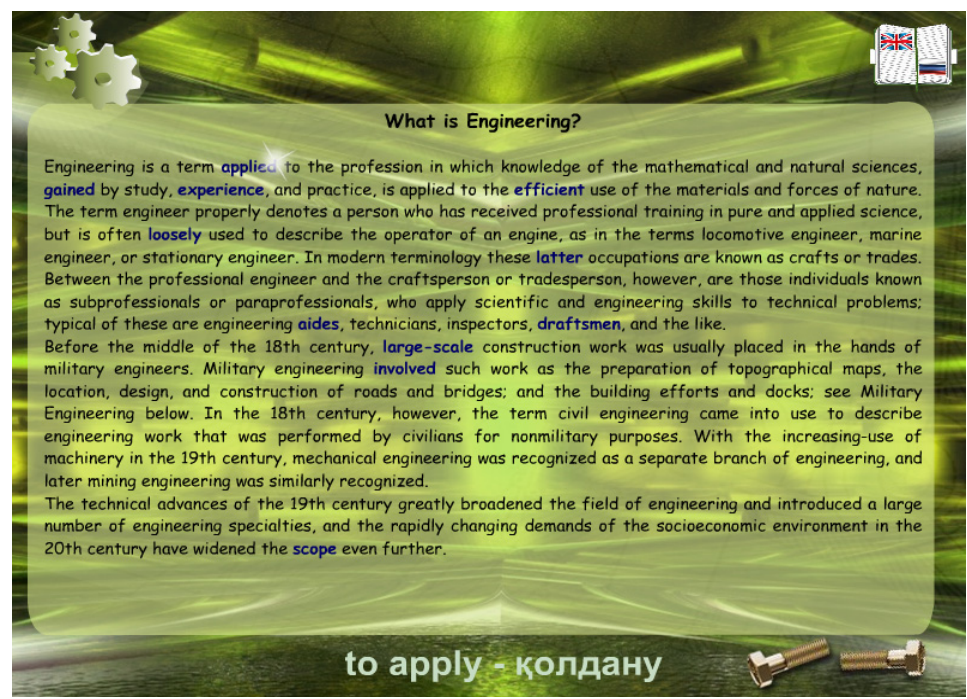

Figure 3 . The text of the lecture

Thesaurus content is a trilingual glossary. Professional terms in the fields of Physics, Mathematics and Computer Science are presented in English-Russian-Kazakh terminological dictionary.

During dictionary writing, authors consulted with Russian-Kazakh Dictionary on Physics authored by Tleukenov, Bibolov, Zhukenov, Russian-Kazakh Dictionary on Mathematics by Abdimanapov, Igilikov; Russian-Kazakh, Kazakh-Russian Dictionary on Mathematics by A. Kussainov; systematized Dictionary of Computer Science by Voroiskiy, English-Russian-Kazakh Dictionary on Informatics by Bidaybekov. The Explanatory Dictionary is dedicated to the students of the faculty of Physics, Mathematics and Information Technology studying English as a compulsory subject.

Work with technical texts in this textbook was conducted in groups with the Kazakh and Russian languages training. The students could use when performing these exercises simultaneously Kazakh, Russian and English. For example, the students of the Kazakh groups tend to know little the Russian language could train, carrying out the English-Russian exercises. And the students of Russian-speaking groups, perform the English-Kazakh exercises, thus repeating Kazakh. The work on the terms includes the following types:

- Classification on the basis of word formation: prefixal-suffix, compound words, acronyms, the formation of new concepts, a truncated form of the word;

- Classification based on nominal, verbal, adverbial grounds; 
- Conceptualization of the objects (material and abstract), activities (processes, operations, actions), the differentiation properties of objects, by species and typological characteristics of the definition of terms;

- Translation of sentences from English into Kazakh or Russian and vice versa;

- Drawing annotation to the texts in English;

- Preparation of professional communication situations;

- Drawing up a crossword with technical subjects.

\section{Results of Experimental Work}

Experimental work has shown that in the absence of foreign environment, and also in the terms of a small number of hours for foreign language training the use of electronic and multimedia courses can improve the skills of students in all kinds of speech activity.

On the monitoring phase of the experiment the testing on all types of speech activity (listening, reading, monologue, dialogue, polylogue writing and grammatical aspect) was conducted for the detection of engineering students' foreign language competence. The copyrighted «Four Basic Skills» e-learning multimedia course was used for testing (Figure 4).

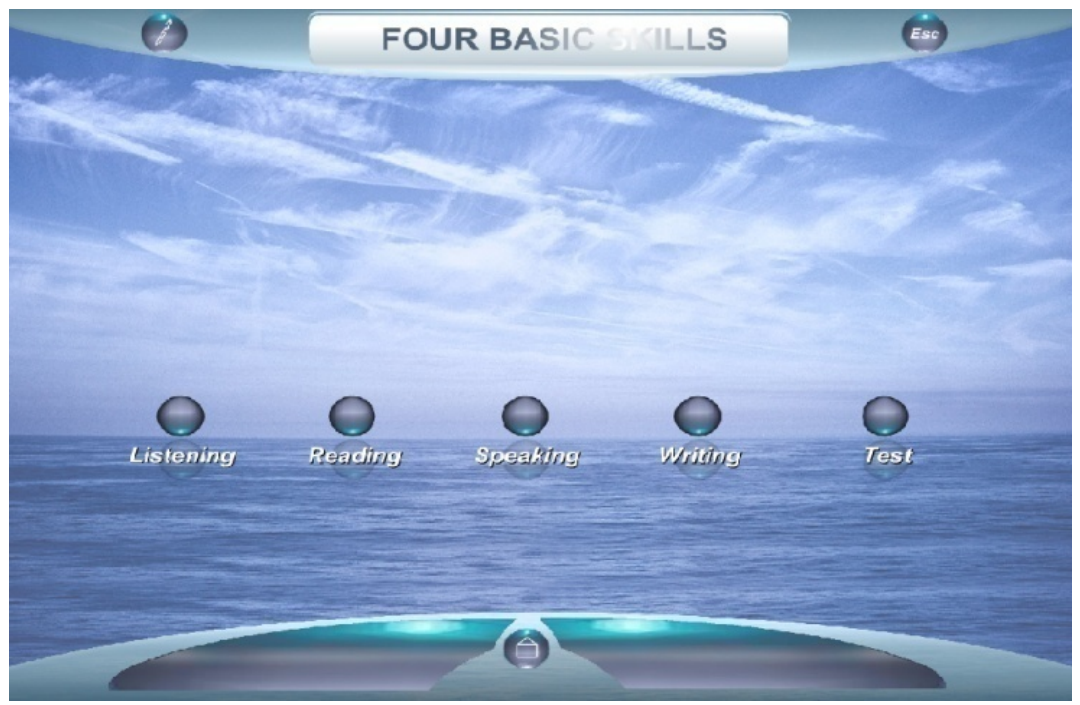

Figure 4. Cover sheet

At this stage of the experiment the results of experimental and control groups were compared. In control groups the formative training was conducted without the use of e-learning courses and other mobile learning tools.

To confirm the correctness of the hypothesis the test results of control and experimental groups were compared that included students of the first, second and third year of faculty: power engineering, Physics, Mathematics and Information Technology, metallurgy, mechanical engineering and transport. In the testing 82 students were involved, including 41 students from experimental groups, where in the process of learning a foreign language mobile learning tools were used.

During testing, it was aimed to verify multilingual competence: development of language, speech, discourse, strategic, lingo-professional competencies.

The "Four Basic Skills"course has been designed on the materials of FCE (First Certificate of English, 2004), IELTS (International English Language Testing System, 2005)

The course contains authentic material by activity: listening, reading, speaking, writing, grammar aspects.

Control stage of the experiment was divided into four ministages.

First ministage: Listening. The students listened to eight texts and had to perform the tasks to check the level of auditive skills (Figure 5). 


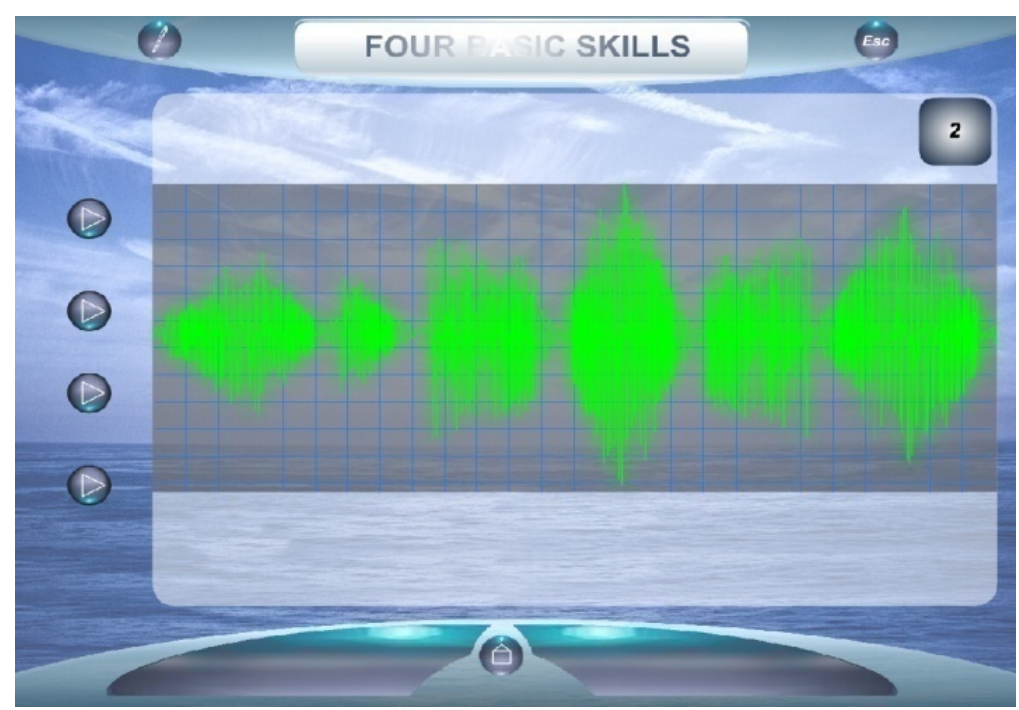

Figure 5. Listening

Second ministage: grammar. The tasks were performed to check the knowledge of vocabulary and grammatical structures.

Third ministage: reading authentic texts and the performance of tasks in order to control the ability of students to extract information (Figure 6).

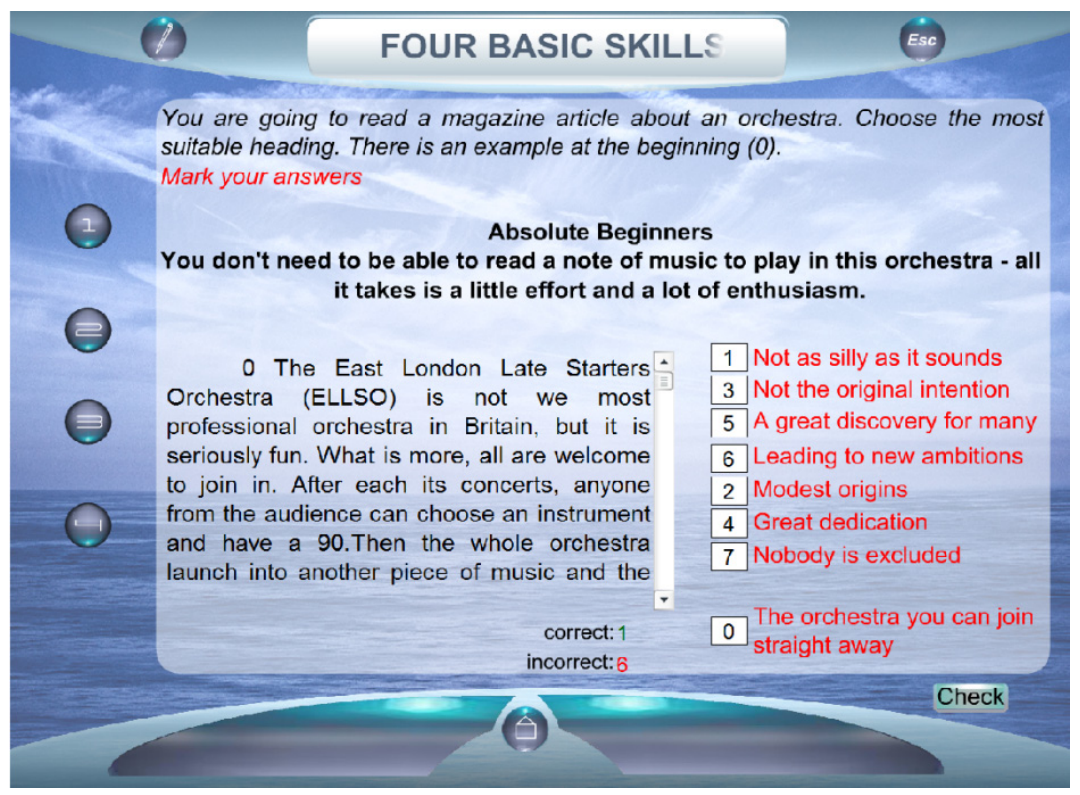

Figure 6. Reading

Fourth ministage: Here, students had to write essays on various topics. The purpose of this step: verification of speaking skills-monologue, polylogue and dialogue.

At the bottom of the window the number of their correct answers has been displayed.

\subsection{Statistics and Data Analysis}

Tables 2-3 present testing data-average assignments for all kinds of speech activity before and after formative experiment. 
Table 2. Test results on all kinds of speech activity

\begin{tabular}{lcc}
\hline Group & Before experiment & After experiment \\
\hline \multicolumn{1}{l}{ Test results on writing } & \\
E & 47.5 & 66.55 \\
$\mathrm{C}$ & 46.7 & 56.15 \\
\multicolumn{2}{l}{ Test results on polylogue } & \\
E & 49.30 & 68.3 \\
C & 48.75 & 56.75 \\
Test results on dialogue & \\
E & 50.23 & 69.31 \\
C & 49.8 & 58.2 \\
Test results on monologue & \\
E & 53.15 & 70.25 \\
C & 52.20 & 61.23 \\
Test results on reading, knowledge of general vocabulary and terms \\
E & 63.4 & 73.83 \\
C & 65.2 & 65.7 \\
Test results on grammar & \\
E & 60.44 & 77.28 \\
C & 56.17 & 65.29 \\
Test results & on listening & \\
E & 57.13 & 76.38 \\
C & 56.84 & 61.76 \\
\hline
\end{tabular}

Table 3. Test results on all kinds of speech activity

\begin{tabular}{lll}
\hline Group. & Before experiment & After experiment \\
\hline E & 54.45 & 71.7 \\
C & 53.66 & 60.72 \\
\hline
\end{tabular}

Table 4. Dynamics of foreign language competence development by basic skills before and after the experiment

\begin{tabular}{lllll}
\hline Speech activity/Group & control group & \multicolumn{3}{c}{ experimental group } \\
\cline { 2 - 5 } & before experiment & after experiment & before experiment & after experiment \\
\hline \multirow{2}{*}{ Listening } & $\%$ & $\%$ & $\%$ & $\%$ \\
Grammar & 56.84 & 61.76 & 57.13 & 76.38 \\
Reading; vocabulary & 56.17 & 65.29 & 60.44 & 77.28 \\
Monologue & 65.2 & 65.7 & 63.4 & 73.83 \\
Dialogue & 52.2 & 61.23 & 53.15 & 70.25 \\
Polilogue & 49.8 & 58.2 & 50.23 & 69.31 \\
Writing & 48.75 & 56.75 & 49.30 & 68.3 \\
Total & 46.7 & 56.15 & 47.5 & 66.55 \\
Average & 375.7 & 425.08 & 381.2 & 501.9 \\
\hline
\end{tabular}


On the Table 4, we see that there have been significant changes in the results of students of the experimental groups (54.45 and 71.7). The results were processed by Student t-criterion. In the experimental groups: tEmp $=$ 6.3. The resulting empirical value $t$ (6.3) is in the area of importance.

The task of controlling the phase of the experiment is to monitor the results of the experiment and the identification of positive dynamics due to the use in the educational process of mobile learning. The hypothesis of the study was either to confirm or vice versa, to refute, the results of test work.

The results in the tables show higher scores in the experimental groups than in the control ones. The distribution of the results after the application of mobile learning tools is statistically significant. The reliability of the test results was proved by the Student t-criterion.

\section{Discussion}

Mobile learning methods include the principle of "anytime, anywhere", making them available to students as needed. Mobile means use time effectively, and students are not related to time constraints. Mobile technologies support different learning styles simultaneously and interactively. This paradigm changes from e-learning to mobile learning.

However, according to Dzhurinskiy (2010), global experience shows that problems of introduction of new technology is not limited to their use. The focus should be the learner, who should be targeted with the use of the latest technology as a tool of knowledge inscribed in the learning process.

In the absence of authentic foreign language environment, as well as a limited number of hours devoted to foreign language in a technical university, the use of multilingual tools of mobile learning, building on the mother tongue or the language of training, optimizes the learning process, since significantly reduced the time required for learning grammar, vocabulary, specialized terminology, resulting in an improved components of communicative competence, that is, cognitive mental, professional-communicative, motivational and regulatory components.

During the formative experiment, it was observed that students who take an active part in role-playing and business games, conferences and other professional communication situations, showed a high level of responsibility, attention and willingness to help others, indicating the qualitative development of personal competence.

Upon completion of the experimental work there have been significant improvements in the components of multilingual competence, vocabulary, specialized terminology and grammatical aspect, as well as significantly improved motivation, which is a proof of the effective of mobile-assisted language learning.

Experimental work has shown that the use of trilingual e-learning courses with authentic content through the mobile technology can solve the problem of raising the level of engineering students' foreign language competence in a multilingual learning environment.

\section{Conclusion}

The practical significance of this work consists in the development and implementation of mobile language learning aids for increasing the level of engineering students' foreign language competence in a multilingual educational environment.

In the absence of authentic foreign language environment, as well as a limited number of hours devoted to foreign language in a technical university, the use of multilingual tools of mobile learning, building on the mother tongue or the language of training, optimizes the learning process, since significantly reduced the time required for learning grammar, vocabulary, specialized terminology, resulting in an improved components of communicative competence, that is, cognitive-mental, professional-communicative, motivational and regulatory components.

The analysis of the experiment as a whole confirms our hypothesis that the use of multilingual resources of mobile learning leads to optimization of the training process and enhances foreign language competence in all three components in the groups with the Kazakh and Russian language training. . Mobile learning tools allow students to train a foreign language in classroom and extracurricular as well as at any time convenient for them, at a reasonable pace for each student. But the problems associated with rising levels of students' foreign language competence through mobile learning in the multilingual learning environment of Kazakhstani University, not limited to this study. More research is also needed to intensify the learning process for improving Kazakh groups students' language skills. 


\section{References}

Bashmakova, I. (2003). On the development of professional communication skills in a foreign language of non-linguistic specialty students (Bulletin of Moscow State Linguistic University ed., Vol. 477, pp. 24-29). Moscow: Bulletin of Moscow State Linguistic University.

Burimskaya, D. (2008). Program-methodical training support of university students (on the example of English Language Teaching) (Doctoral thesis ed., p. 24). Moscow: Moscow.

Dictionaries and Encyclopedias. (2013). Retrieved March 11, 2013, from http://encbook.ru/content244150/

Dzhurinskiy, A. (2010). Pedagogy in a multicultural world: Studies. Guide for students enrolled in "Pedagogy and Psychology". "Pedagogy" (p. 240). Moscow: VLADOS.

Galperin, P. (1966). Psychology of thinking and teaching about the gradual formation of mental actions (p. 277). Moscow: Nauka.

Kalmanova, D. (2009). Pedagogical conditions for development of informative interest of students using electronic textbooks ( $\mathrm{PhD}$ thesis ed., p. 30, Atyrau).

Kalmanova, D. (2011). The use of electronic textbooks in order to enhance students' cognitive interests. Methods of Teaching a Foreign Language, 5, 30-34.

Kussainov, A. (2008). Comparative Education (p. 251). Almaty: Education.

Leontiev, A. (1971). The theory of speech activity (p. 294). Moscow: Higher Pedagogy.

Minkova, E. (2005). Integration of information and communication technologies and traditional approaches to teaching humanities university students ( $\mathrm{PhD}$ thesis ed., p. 208, Stavropol).

Mullamaa, K. (2010). ICT in Language Learning-Benefits and Methodological Implications. Tartu: Language Centre, University of Tartu, Estonia. http://dx.doi.org/10.5539/ies.v3n1p38

Obraztsov, P. (2001). Information technology support of educational process in the university (\#6 ed., pp. 25-28). Moscow: Higher Education in Russia.

Pfeifer, N., \& Zhumatayeva, E. (2006). Informatization of the educational process at the objects of higher education. Computational and Informational Technologies for Science, Engineering and Education, 2, 138. Pavlodar: ECO.

Piaget, J. (2001). Theory, experiment, discussion (p. 624). Moscow: Gardariki.

Rubinstein, S. (1989). Fundamentals of general psychology (Vol. 1, pp. 192-193). Moscow.

Skinner, B. (1968). The Technology of Teaching. (Appleton Century-Crofts ed., p. 271).

Vygotsky, L. (1960). The development of higher mental functions (p. 500). Moscow: Publishing House of the Academy of ped. Sciences.

Yamaguchi, T. (2005). Vocabulary learning with a mobile phone (Program of the 10th Anniversary Conference of Pan-Pacific Association of Applied Linguistics, Edinburgh, UK. ed.).

Zaitseva, E. (2004). The principles of accessibility and communicative training of students in the conditions of using information and communication technologies (p. 183) ( $\mathrm{PhD}$ thesis, Stavropol).

\section{Copyrights}

Copyright for this article is retained by the author(s), with first publication rights granted to the journal.

This is an open-access article distributed under the terms and conditions of the Creative Commons Attribution license (http://creativecommons.org/licenses/by/3.0/). 